\title{
Resistance Characteristics of Pork Meatballs and Beef Meatballs Using Multimeter
}

\author{
Moh. Yasin Faidlul Qodir", Nadia Rahmaningrum ${ }^{* *}$, Frida Agung Rakhmadi*** \\ Physics Department, Faculty of Science and Technology, UIN Sunan Kalijaga \\ J1. Marsda Adisucipto No 1 Yogyakarta 55281, Indonesia. Tel. +62-2744-540971, Fax. +62-274-519739 \\ E-mail: mohyasinfaidlulqodir@gmail.com*, nadiarahma930@gmail.com ${ }^{* *},{ }^{3}$ frida.rakhmadi@uin-suka.ac.id ${ }^{* * *}$
}

\begin{abstract}
Meatballs is food typical Indonesian that has taste delicious. It is even the most preferred food for Indonesian people. The ingrediants used in meatballs is meat, flour and etc. Most Indonesian people are Muslim. So, not carelessly eating meatballs made from meat (Pork). The purpose of this study is to find out whether meatballs use pork or not, using the resistance method with a digital multimeter. Resistance is the ability to inhibit electricity. This trial uses pork meatballs and beef meatballs 5 times a try on each meatball. Resistance values were obtained for pork meatballs 3,718 $\Omega$ and for beef meatballs 2,988 $\Omega$. From the data obtained, the resistance value in pork meatballs is higher than beef meatballs.
\end{abstract}

Keywords: Beef meatballs, Multimeters, Pork meatballs, Resistance

\section{INTRODUCTION}

The meatballs are a favorite food of Indonesian society or foreigners visiting Indonesia. The meatballs have a diverse taste coupled with meatball sauce made of some spices typical of Indonesia. Currently, there are several types of meatball that could be an option for consumption. Such as veal meatballs, pork meatballs, chicken meatballs, meatball mix of beef and chicken meatballs, meatballs firecrackers and many others.

Because the majority of Indonesian people are Muslims and forbids to eat unclean foods, the meatball seller must include the logo on meatballs sells kosher. However, there are some business owners who sell meatball does not match the name. As they write with writing veal meatballs, but it turns out the unscrupulous sellers use is the main ingredient for pork meatballs.

Currently, pork and beef are difficult to distinguish at a glance so that consumers do not know exactly the type of meat that will be purchased. The rise of counterfeiting is what causes anxiety and loss of customers. Tests indicated adulterated meat samples (beef false), usually done with a physical exam and laboratory testing. Meanwhile, laboratory tests require a relatively long time and can not be done in the case (read: the merchant) and the new results tomorrow (Ayu, 2012).

However, once the meat is processed into meatballs then it would be difficult to distinguish anymore because it was mixed with a few extra ingredients to make dough balls. Thus, consumers are less thorough and meticulous in distinguishing between beef or veal meatballs meatballs. To cope with that then, researchers distinguish between the veal meatballs and pork meatballs by measuring the resistance using a multimeter.

\section{MATERIALS AND METHODS}

\section{Tools and Materials}

The materials needed are sampled pork meatballs and beef meatballs samples. In this case, for the size of cattle and beef meatballs meatballs nearly the same.

The tools used in data collection is a 2 pins, ice cream sticks, cable and digital Multimeter.

\section{Data Collection Methods}

After preparing the tools and materials that have been needed, the next step was to capture the data. The retrieval of data using a digital multimeter. In a few references exist, studies using the resistance of the multimeter has never been used or discussed. The principle of this tool is to stick two pins with a distance between the needle $\pm 1 \mathrm{~cm}$ and connected with a cable that has been connected to a digital multimeter which will then be out the value of its resistance.

By doing variation measurement 5 times for each sample and data collection is in the Lab space with room temperature $32^{\circ} \mathrm{C}$. Data and graphics that have been obtained and analyzed how characteristics which can then be used to determine if the data will be continued or not in the manufacture of detection devices.

\section{Data Processing}

The above data processing method is by determining the average value of the resistance by using the equation:

$\overline{\mathrm{X}}=\frac{\sum R n}{n}$

By: $\mathrm{R}=$ the resistance

$\mathrm{n}=$ number of samples 
Having obtained the resistance, followed by substituting the data to Ms. Excel to obtain a graph of the results of different test characteristics of meatballs.

\section{RESULTS AND DISCUSSION}

\section{Data Processing}

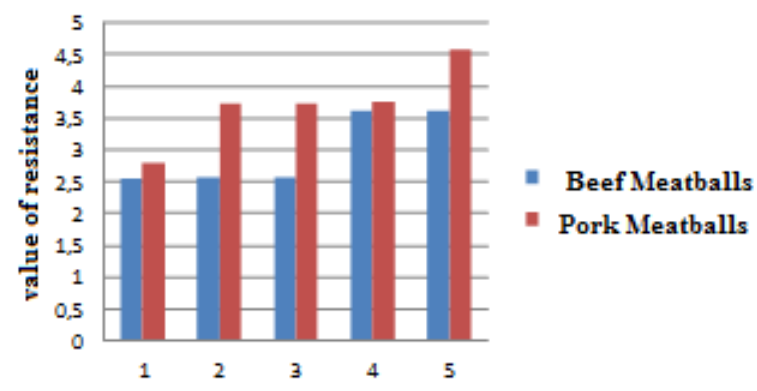

Figure 1. Graph beef meatballs and pork meatballs resistance.

Table 1. The results of data retrieval resistance method.

\begin{tabular}{ll}
\hline Beef Meatballs $(\boldsymbol{\Omega})$ & Pork Meatballs $(\boldsymbol{\Omega})$ \\
\hline 2,54 & 2,79 \\
2.57 & 3.74 \\
2.57 & 3.74 \\
3.63 & 3.7 \\
3.63 & 4.57 \\
\hline
\end{tabular}

Results obtained retrieval of data in table 1 . The average value obtained from the data processing using the equation is $2.988 \Omega$ to sample the veal meatballs and $3,718 \Omega$ to sample pork meatballs. Then the data in Table 1 are substituted into Ms. Excel and get a figure 1.

\section{Data Analysis}

From some research on pork and beef before, that the characteristic texture of pork and beef are different. If pork texture is soft and elastic. While beef is more rigid and solid. From there we can know the mass meetings also play a role in this research. Based on the resistance value is obtained and taken on average, the value of resistance in pork meatballs higher than beef meatballs.

Figure 1 shows samples of beef meatball and pork meatballs samples intersect, where the beef meatball samples are in the range 2.5 to 3.6 range. While the pork meatballs samples are in the range 3.7 to 4.5 range. Data tersebutd apat clearly distinguishable surface tension value. Therefore, from these data can be used as a basis for the manufacture of detection system.

\section{CONCLUSIONS}

Based on research has been done, it can be concluded that resistance values were obtained for pork meatballs $3,718 \Omega$ and for beef meatballs $2,988 \Omega$. Based on the resistance value is obtained and taken on average, the value of resistance in pork meatballs higher than beef meatballs. Therefore, from these data can be used as a basis for the manufacture of detection system.

\section{ACKNOWLEDGEMENTS}

Thanks authors say to all thos who have supported and helped research as well as in writing. We say thanks to Mr. Frida Agung Rakhmadi the our supervisor who gave ideas and guidance.

\section{REFERENCES}

Fibriana, F., Widianti, T., Retnoningsih, A., dan Susanti. 2012. Deteksi Daging Babi pada Produk Bakso di Pusat Kota Salatiga Menggunakan Teknik Polymerase Chain Reaction. Jurnal Biosantifika 4(2): 106-112.

Irawati, Y. (2001). Pemanfaatan Primer Pengapit PRE-1 (Porcine Repetitive Element) untuk mendeteksi Daging Babi Pada Beberapa Produk Sosis.Skripsi. Bogor: Institut Pertanian Bogor.

Muladno, D. M. \& Budiartai, S. (1999). Mendeteksi bakso yang mengandung daging babi. Med. Pet. 23(1), 14-17.

Rohman, A., Erwanto, Y., Sismindari dan Jacob, C.M. (2011). Analysis of pork adulteration in beef meatball using Fourier Transform Infrared (FTIR) spectroscopy. Meat Science 88: 9195.

Shera Mayangsari Suwito, B. H. (2012). Klasifikasi Jenis dan Kualitas Daging Konsumsi Berdasarkan Analisis Tekstur dan Warna dengan Metode Transformasi Curvelet dan K-Nearest Neighbor. Bandung: Universitas Telkom.

Soeparno. (2009). Ilmu dan Teknologi Daging. Yogyakarta: Gadjah Mada University Press.

Sudarwati. 2007. Pembuatan bakso daging sapi dengan penambahan kitosan. Skripsi Sarjana. Fakultas Pertanian. USU.

Sunarlim, R dan Triyantini. 2000. Penggunaan berbagai konsentrasi nacl dan jenis daging terhadap mutu bakso. Jurnal Balai Besar Penelitian dan Pengembangan Pasca Panen Pertanian. Bogor. 